Article

\title{
Romanian Business Leaders' Perceptions of Business-to-Business Corruption: Leading More Responsible Businesses?
}

\author{
Sebastian I. Burduja * and Rodica Milena Zaharia * \\ Research Center in Business and Economics (CCREI), The Bucharest University of Economic Studies, \\ 010374 Bucharest, Romania \\ * Correspondence: tianu@post.harvard.edu (S.I.B.); milena.zaharia@rei.ase.ro (R.M.Z.)
}

Received: 29 July 2019; Accepted: 3 October 2019; Published: 9 October 2019

check for updates

\begin{abstract}
Business-to-business (B2B) corruption, also known as private corruption, refers to unethical or illicit activities between private parties, without the direct participation of the state. Existing literature on the topic, while still limited, has taken several avenues, from qualitative studies to perception-based surveys and research experiments. Upon reviewing key studies and their findings, this article concentrates on research questions related to: business people's perceptions on the determinants that favor B2B corruption in Romania, consequences of the phenomenon, and potential solutions. Findings are based on primary data collected through a 2019 questionnaire administered to 120 business leaders in Romania. Results confirm earlier studies' findings that general context, malfunction of the institutions, and mentality favor B2B corruption, and that there is a lack of consensus among the business community on how to recognize and deal with various forms of B2B corruption, despite the widely spread belief that B2B corruption negatively affects business activities. Also, both internal and external solutions are considered to work against B2B corruption. The current article also opens new avenues in the literature, showing that: the probability to face B2B corruption increases with business leaders' professional experience; preferences on how to deal with corruption cases vary based on a firm's capital structure (domestic vs. foreign), reflecting the importance of organizational culture; and business leaders overwhelmingly want to fight against B2B corruption through both internal and external measures. Substantial progress, however, will require a proper common understanding by the private sector of what constitutes B2B corruption, including its causes, consequences, and remedies.
\end{abstract}

Keywords: business-to-business (B2B) corruption; private corruption; anticorruption; responsible business; determinants of B2B corruption; Romania

\section{Introduction}

Corruption remains a contentious, ambiguous, and insufficiently explored phenomenon, particularly when it comes to business-to-business (B2B) relations. Corruption is broadly defined as "the misuse of office for unofficial ends" [1], whereby "office" may refer to positions of authority in either public or private entities. Some concrete examples of B2B corruption cases include: company A's employee pays off company B's employee to close a deal or secure some other benefit (e.g., a kickback to obtain more or better shelf space for A's products in B's retail shops); company A's manager buys a product or service from company B because his relatives or friends work for company B (i.e., nepotism); company A's employee sells privileged information to company B in exchange of a fee; etc. Such B2B corruption cases happen all the time around the world and are recognized as such in both international and national law, including the United Nations Convention against Corruption (UNCAC) and the European Union's 2003 Framework Decision on combating corruption in the private sector [2]. 
Beyond its high prevalence and costs, corruption is an inherently covert phenomenon, making it hard to define, measure, and understand [3]. These challenges are even greater when it comes to B2B corruption. B2B corruption involves the "misdirection of organizational resources for personal or organizational benefit" [4]. This implies a lack of accountability for the potential consequences on society. By contrast, many scholars argued that firms have to act in accordance with "the objectives and values of our society" [5]. This latter perspective would require businesses to fight actively against corruption if it goes against societal objectives and values, presumably even at the expense of business profitability, at least in the short term. Over the long run, adhering to corrupt practices can hurt a company's competitiveness and viability.

A related debate centers around the question of whether transactions between private parties may actually count as corruption. In other words, is corruption a concern when no public money is involved? If so, why? One possibility is that free market mechanisms between profit-maximizing entities eliminate inefficiencies, including different forms of corruption: commercial bribery or kickbacks, solicitation, fraud, nepotism, conflicts of interest, the use of privileged information, etc. [6]. After all, if a company is to survive in the long term, competition requires corruption-free behavior that maximizes profits and minimizes reputational and legal risks. However, principal-agent dynamics based on information asymmetries open possibilities for corrupt deals whereby personal gains take precedence over shareholders' interests.

With the evolution of the specialized literature and legal framework, this dilemma has been largely resolved since the early 2000s in favor of Argandoña's view that "private-to-private corruption is no less important, no less widespread, no less harmful and no less worth combating than private-to-public corruption" [7]. Multiple studies have shown that B2B corruption does exist and poses serious risks to both businesses and societies at large: inefficient allocation of resources; weaker competition leading to more expensive and lower quality products and services; higher risks for public health and the environment; unethical norms transferred across society through employee mobility, etc. $[7,8]$. Ultimately, recognizing and fighting against B2B corruption comes down to principles, as Argandoña shows: (1) employees' fiduciary duties and loyalty requirements toward company shareholders; (2) free competition and consumer protection; (3) property protection (anti-fraud); and (4) special legal provisions against insider trading, industrial espionage, etc. [7].

In the Romanian context, corruption is considered rampant and profoundly damaging, across all sectors of the economy, including both petty and grand forms [9]. It was a key focus during Romania's effort to join the European Union (EU), and remains of critical concern to the European Parliament and the European Commission [10]. Most perception-based surveys rank Romania as one of the most corrupt countries in the EU [11]. At the same time, there is a relatively high level of mistrust in private employers in Romania, and one of the top factors is perceived unethical behavior by firms [12]. Beyond these data, there are virtually no studies on the prevalence of different forms of public versus private corruption. These phenomena are either mixed together, as in Transparency International's Corruption Perception Index (CPI), or reports cover public corruption only, as is the case with the EU's Cooperation and Verification Mechanism (CVM) series.

The current article seeks to fill this void by exploring B2B corruption in Romania, including its prevalence, determinants, consequences, and potential solutions through a baseline survey of 120 business leaders active on the local market. This study is the first of its kind to gather and evaluate systematic data on private corruption in Romania, thus adding to the literature key empirical data. Also, this work confirms the results of the few existing studies on private corruption, consolidating the theoretical background on the topic of $\mathrm{B} 2 \mathrm{~B}$ corruption. Another contribution to the literature is given by some new findings that add to those mentioned by other studies: the role of media as an anticorruption measure and absence of salary-related anticorruption measures. These new insights revealed by our study confirm the infancy of the existing research on this topic and the importance of empirical studies such as the current article. 
Ultimately, the limited data-and corresponding difficulties of assessing corruption in the very sensitive Romanian business environment-only allow for drawing preliminary conclusions, but the current study does provide a primary, vital starting point for much needed research on the topic of B2B corruption in Romania, the European Union, and globally.

In what follows, this article briefly discusses available literature on corruption generally, on B2B corruption and its determinants specifically, and on how corruption erodes the responsibilities businesses have toward society. The sources on B2B corruption are limited, and the topic of private corruption remains unexplored by many scholars and policymakers alike. Then, this study explains the research methodology and its key limitations. The next section presents the main findings of the research and contextualizes them, followed by a discussion of the key insights. This includes comparisons with a similar study in Denmark and Estonia, noting, however, that there is limited scope for drawing definitive conclusions across countries because of the different sampling techniques. The last sections conclude, offer suggestions for future avenues for research, and underline the implications of this study for business education and for the business community at large.

\section{Literature Review}

The literature on corruption is relatively recent, and paradigms have changed over time, from cultural to functional or to political arguments. A primary question relates to what constitutes corruption and whether the phenomenon is harmful or beneficial for society. Cultural relativists point out that something considered corruption in one society may be viewed differently elsewhere, or that there are particular traits in some cultures that make them more prone to permit or even encourage corruption [13]. Critics counter that cultural practices like gift-giving may be used to facilitate corruption, but do not cause it [14].

For their part, some functionalists $[15,16]$ have argued that corruption is in fact useful for emerging economies as a way to "grease the wheels" of slow bureaucracies, promoting investment and development. However, as early as 1974, economist Anne Krueger responded to such claims by showing that bureaucrats are the main beneficiaries of procedural inefficiencies [17]. Political scientists have also explored corruption's impact on societies' democratic development. As Larry Diamond notes, "no problem more alienates citizens from political leaders and institutions and undermines political stability and economic development than gross, endemic corruption on the part of government and political party leaders, judges, and officials up and down the bureaucratic hierarchy" [18].

For the past several decades, the global community of scholars and policymakers has reached broad consensus on the profoundly damaging nature of corruption and the need to combat it. Key studies have demonstrated corruption's negative impact on development [19], including through the squandering of resources, the erosion of democratic legitimacy, and as an "additional tax" [20] on new and current businesses. Instruments like Transparency International's Corruption Perception Index (CPI) are now widely cited and used to evaluate a particular environment's economic and political features. Legally, corruption is punished throughout the free world, both domestically and internationally. For instance, in 2018 alone, the US imposed over $\$ 2$ billion in penalties related to breaches of the Foreign Corrupt Practices Act (FCPA), whereby companies are forbidden to bribe foreign officials [21]. The vast majority of such efforts, however, only focus on government-related corruption, also referred to as political corruption or public-to-government corruption, i.e., "behavior [that] deviates from the formal duties of a public role (elective or appointive) because of private-regarding wealth or status gains" [22].

\subsection{B2B Corruption}

Many scholars consider that businesses should behave in accordance with the carefully thought-out rules of moral philosophy [23], in line with the objectives and values of our society [5,24]. Failure to meet these expectations of ethical behavior can harm a firm's reputation, with potentially catastrophic results to shareholder value [25]. If a company wishes to be perceived as a reliable partner in business, it has to act ethically and responsibly [26]. This perspective would require businesses to fight actively 
against corruption if it goes against societal objectives and values, presumably even at the expense of business profitability, at least in the short term. Over the long run, adhering to corrupt practices can hurt a company's competitiveness and viability.

There has been little scholarly and policy interest for the issue of private-to-private or business-to-business (B2B) corruption, despite the fact that agreed definitions and instruments cover both private and public forms of corruption. The literature provides a wide range of definitions, from abuse of power to misuse of resources for private benefit. Transparency International, for instance, defines corruption as "the abuse of entrusted power for private gain" [27]. The OECD explicitly notes that corruption is "the abuse of a public or private office for personal gain" [28]. In their 2004 article, Anand, Ashforth, and Joshi further note that corruption as the misuse of an organizational position "refers to departures from agreed societal norms" [29]. For the purposes of this article, private or B2B corruption can be defined as the abuse of authority in transactions between private parties to extract undue benefits.

Beyond definitions per se, it is important to explore the reasons behind the reduced focus by scholars and policymakers on private corruption. Some argue that transactions between private parties are typically private matters, and any potential conflicts are typically resolved internally [7] (p. 253). Also, as profit-maximizing entities, private companies should be capable of eliminating any transaction that hurts their bottom line. Based on classical liberalism, the "invisible hand" should inevitably guide business organizations in the right direction [30]. Others note that private actors are simply subject to less scrutiny, as they do not deal with taxpayer money, so company employees typically have "a bigger scope for arbitrary decisions," particularly in procurement [31]. These arguments, while valid, do not justify failing to investigate and sanction private corruption. Indeed, key stakeholders (shareholders, management, etc.) may have the desire but not the knowledge or capacity to perceive and combat corruption acts unfolding in their companies, as shown below.

In arguably the first article on the topic, Argandoña describes the full list of forms of B2B corruption: "bribery (when it is the person who pays who takes the initiative); extortion or solicitation (when it is the person who receives the payment who takes the initiative, whether explicitly or otherwise); dubious commissions, gifts, and favors; facilitation payments (to speed up completion of an order, delivery of goods or payment of an invoice, for example); nepotism and favoritism (in the hiring and promotion of personnel, for example); illegitimate use or trading of information (trade or industrial secrets, for example); use of undue influence to change a valuation or recommendation; and an endless array of other possibilities born of human ingenuity over the centuries" [7] (pp. 255-256). The same author [7] argues that B2B corruption is punishable by law primarily based on: breaches of fiduciary trust; undermining of free market competition; fraud; insider trading, etc. B2B corruption negatively impacts market-based mechanisms, creating inefficiencies, eroding trust among businesses, harming employees' loyalty toward their companies and respective shareholders, and contributing to a general societal culture of corruption [7]. There is therefore a prevailing view that B2B corruption is indeed harmful, both for individual businesses and society as a whole.

Current international laws confirm this perspective. Recognizing the risks and costs of the phenomenon, as early as the 1990s the international community adopted important acts designed to combat corruption and B2B corruption specifically. These include: the Inter-American Convention against Corruption (1996) [32], the OECD Convention on Combating Bribery of Foreign Public Officials in International Business Transactions (1997) [33], the EU's Joint Action on Private Corruption [34], the Council of Europe's Criminal Law Convention on Corruption (1999) [35], and the EU's Council Framework Decision 2003/568/JHA [36] on combating corruption in the private sector (2003). Often cited is the United Nations Convention against Corruption (UNCAC), also adopted in 2003, which includes specific provisions on B2B corruption under Article 21, covering the demand and supply sides (i.e., both requests and offerings of "undue advantage" to act or refrain from acting, in breach of duties) [37]. These international initiatives are vital as a signal that B2B corruption exists and requires 
attention, though international conventions like the UNCAC are not directly enforceable at the level of each signatory.

As the specialized literature shows, combating B2B corruption requires much more than legal instruments, and the most effective measures appear to be bottom-up, i.e., starting at the level of each private entity. Anand, Ashford, and Joshi offer an in-depth account of tactics to rationalize and socialize corruption, including denial of responsibility, denial of injury, cooptation, incrementalism, etc. [29]. All these lead to corrupted perceptions of behavior, whereby perpetrators appear to act morally and those opposing them are gradually converted to such practices or excluded from the organization. Such behavior can easily translate to an entire sector, business environment, and society. It is therefore vital to find out how business people understand the phenomenon and how they explain it.

\subsection{Determinants of Private Corruption}

The literature on B2B corruption shows that it is often challenging to perceive, recognize, measure, and fight against it. Surveys may underestimate the scale of the phenomenon, as they can miss some of the determinants favoring corruption [38-41]. For one, due to the illegal and covert nature of corruption, research subjects may not want to share their experiences for fear of potential repercussions in terms of legal penalties, reputational costs, etc. Moreover, quantitative surveys have to be based on perceptions, which are inherently subjective. As noted by Kaufmann, Kraay, and Mastruzzi, "perceptions of corruption based on individuals' actual experiences are sometimes the best, and the only information we have" [41]. In terms of business attitudes and investors' trust, perceptions may matter more than reality; in other words, if a country's private sector is perceived as very corrupt, there will be dire economic consequences in distorted competition and limited investment, regardless of whether corruption is real or not.

A 2008 exploratory study by C. Gopinath demonstrated the complexity of private corruption assessment (recognizing and justifying B2B corruption) and identified determinants of corruption at the private level (cultural reasons, mentality, and lack of moral principles). The author surveyed students from a business school in North America to explore their perceptions and attitudes vis-à-vis private corruption [42], and sought answers to three distinct research questions: (i) Are individuals able to recognize ethical issues in private transactions? (ii) What arguments do they use to justify unethical behavior? (iii) Would individuals act differently when faced with public vs. private corruption?

Gopinath [42] administered a brief questionnaire presenting a hypothetical scenario faced by the manager of a company visiting a partner organization in India. A clerk in the Indian company notes that he can speed up import papers if he is paid overtime by the visiting manager. There is also an option to pay something to the customs officials. The manager has to decide whether to accept or refuse the requested payments. Gopinath found that indeed individuals had difficulty recognizing bribery in the case of private corruption. The qualitative assessment of the sample reasons provided for their decisions shows that respondents justify making the payment for business reasons, noting that it is a harmless bribe, that it is common practice in developing countries, or that facilitation payments are not illegal. There was no standardized assessment of the situation. Only $20 \%$ referenced moral principles in making their decision, while $11 \%$ of respondents cited cultural reasons, some noting that India is known for the wide prevalence of such practices [42].

In the case of B2B corruption, the added complication in explaining it is that some subjects may not even see it as such. Particularly because there is no public money involved, perpetrators themselves-along with those around them, e.g., colleagues, business partners, etc.- - tend to justify corrupt actions by claiming they are actually furthering their respective companies' interests in an environment where others may be resorting to the same tactics [29]. The general context, cultural norms, as well as the complexity of bureaucracy are among the determinants that explain private corruption. Firms might be engaging in corruption among themselves to strategically counter perceived bureaucratic power [43] (p. 759). The degree of corruption may be determined by the level of economic freedom, socio-political stability, tradition of law abidance, and national cultures [38]. Studies mention 
economic variables (government consumption, level of development), governments effectiveness, and cultural factors as determinants that significantly affect corruption [44-46].

Beyond such inherent challenges, there are still only a few quantitative surveys focused on B2B corruption, as much of the research continues to focus on corruption in the public sector, including the two key instruments from Transparency International (TI): the Corruption Perception Index (CPI) [47] and the Global Corruption Barometer (people's experiences with bribing officials for basic services) [48]. Some surveys like TI's 2011 "Putting Corruption Out of Business" [49], the Flash Eurobarometer 374 "Business Attitudes towards Corruption in the EU" [50], the World Bank's BEEPS survey [51], and the "International Business Attitudes toward Corruption" study by Control Risks [52] are useful in understanding the prevalence of corruption in various countries' private sectors, as well as available tools for businesses seeking to combat this phenomenon. However, these studies fail at distinguishing between public and private corruption. Most questions, in fact, refer clearly to transactions in business-to-government (B2G) or equivalent relations-i.e., winning public tenders, obtaining construction permits, financing political parties, etc. [50].

Notably, TI's Bribe Payers Index (BPI) does include for 2011, the most recent year available, specific questions on B2B corruption [53]. The BPI ranks 28 countries based on their respective business executives' answers around paying bribes when operating abroad, on a scale of 0 (always bribe) to 10 (never bribe). For the first time in 2011, the BPI also asked over 3000 executives about how often firms in each sector "pay or receive bribes from other private firms" [53] (p. 18). The results show that B2B corruption is more prevalent in public works and construction, utilities, real estate, and oil and gas, and less prevalent in agriculture, light manufacturing, IT, and banking and finance. Interestingly, there are no significant differences perceived between prevalence rates for petty/grand B2G corruption and B2B corruption: "this provides evidence that corruption is not just a phenomenon that involves public servants abusing their positions, but it is also a practice within the business community" [53] (p. 19). As TI further notes, while B2B bribery remains often overlooked, its consequences are very serious, including distorting markets, increasing costs to firms and consumers, and penalizing those corporate actors who either cannot or will not engage in corrupt acts vis-à-vis other firms.

For its part, the European Union has started to devote increasing attention to B2B corruption, including through funding of research studies, which further strengthens the view that this is a deeply harmful phenomenon requiring clear focus and solutions. One example is the 2013 report on Croatia, which measures the prevalence of B2B bribery-in Croatia vs. the Western Balkans-as "the number of businesses who gave money, a gift or counter favor, in addition to any normal transaction fee, on at least one occasion in the 12 months prior to the survey to any person who works, in any capacity, for a private sector business entity, including through an intermediary" [54] (p. 37). The research also compared business sectors in terms of private corruption prevalence, forms of payment (most often, exchange with another favor, while cash or other benefits are least frequent), modality (in $60 \%$ of the cases a bribe request is made), and timing (most at the same time as the service delivery). Reporting rates are extremely low: in less than $1 \%$ of the cases, the police are informed about B2B bribes [54] (p. 48).

Another EU-funded study is the Private Corruption Barometer [6], also known as Project PCB, which was launched to fill the gap in available data on the perception and experience of B2B corruption, as well as to agree on a set of common indicators to measure this phenomenon across the EU. Project PCB covered four Member States, including Bulgaria, Italy, Spain, and Germany, with national samples including both small/medium/large companies (in terms of number of employees) and covering different sectors (industry, trade, services, hotels/restaurants, and construction). The questionnaire covered multiple areas: general B2B corruption perceptions; experiences (knowing someone who had been offered gifts/money/other benefits); and anticorruption measures' effectiveness, from termination of contracts to internal control systems. Overall, the study shows similar attitudes vis-à-vis B2B corruption in Germany, Italy, and Spain, with clear differences compared to Bulgaria, where the phenomenon appears to be both more prevalent and more accepted among survey respondents. 
Arguably the most extensive study of B2B corruption funded by the EU is the 2016 PrivaCor, which compares the phenomenon in Estonia and Denmark, having interviewed 500 managers in each country [55]. The authors justify the study by noting that "most EU countries lack information about the extent and forms of corruption in the private sector" [48] (p. 8). To fill this void, the research looks at: forms and frequency of B2B corruption; excuses/justifications given for corruption acts by private actors; awareness of consequences; and recommended measures to combat corruption through improved business practices.

Multiple findings of the PrivaCor study help shed light on B2B corruption. For one, the phenomenon is present and significant in both states: $57 \%$ of Estonians and $51 \%$ of Danes had encountered at least one type of corruption within their sector, with kickbacks and conflicts of interest as the most prevalent. The main excuses for corruption are similar in both countries: pressure from upper management, followed by "everyone else does it." Smaller companies and local-owned firms are more likely to invoke excuses compared to larger or foreign-owned businesses. The main consequences feared by respondents are damages to the company's reputation and financial losses, while "male managers are more concerned about the negative effects on their own careers than their female colleagues" [55] (p. 5).

In terms of solutions for combating corruption, studies underline the importance of both internal and external solutions $[7,43,46,55,56]$. PrivaCor shows the willingness of respondents in both countries to act. Only 3\% of managers in Estonia and 10\% in Denmark would not blow the whistle on a corruption case, and the vast majority would handle the issue internally. Over $90 \%$ of subjects in both countries note that managers' personal example can be effective to fight corruption. Another important conclusion is that guidelines and public awareness of B2B corruption continue to lack in both countries. There are also some differences: "only $27 \%$ of Estonian managers find law enforcement (police or prosecutors) effective, compared to $72 \%$ of the Danish managers" [55] (p. 5). Danish managers also value trainings and ethical standards more than their Estonian counterparts. Other recommendations to fight against B2B corruption are: develop a toolkit for identifying high-risk areas within each company; hire the right people, including by accessing proper background checks; and clarify procedures for reporting (e.g., hotlines, independent trustees, etc.).

Along the same lines, in his seminal 2003 study of B2B corruption, Argandoña recommends clear and transparent standards, with specific examples of potentially problematic situations, specialized trainings, as well as drastic sanctions, as needed [7]. Anand, Ashford, and Joshi make similar suggestions to combat the phenomenon: adoption of codes of ethics, actions to promote awareness, design and enforcement of whistleblowing protections, involvement of external change agents [29]. Goel, Budak, and Rajh show that, among different anti-corruption policies (including internal and external measures), a firm's internal code of ethics proved to be an effective deterrent [43]. Rose-Ackerman also emphasizes the importance of company-led measures, including personnel policies for hiring people with strong morals, along with credible whistleblowing mechanisms [56].

It is clear from the review above that more empirical research, investigating the determinants of B2B corruption in different contexts, as well as exploring business leaders' understanding of the phenomenon help develop appropriate solutions to fight against this social disease.

\subsection{Corruption in the Romanian Context}

Societies with a long tradition in rule of man instead of the rule of law register high levels of corruption [57]. During the communist period, Romania (as other communist countries) followed the rule of man, as the law served primarily the interests of the nomenklatura [58]. The transition period did not create the conditions for strong rule of law; if fact, it brought even more confusion regarding the role of institutions, the legitimization of business, and people's trust in market economy mechanisms. The corruption cases related to the privatization process generated high public skepticism regarding the fortunes amassed by some, in a short period of time, particularly former activists, their friends or relatives, or former directors of state-owned companies [59] (p. 667). 
Indeed, for decades, Romania has been perceived as one of the most corrupt countries in Europe, a story confirmed by all major perception-based surveys and indicators. In 2018, Romania's CPI score was 47, placing the country as the fourth most corrupt in the EU, closely behind Hungary, Greece, and Bulgaria [60]. Other indicators support this view. TI's Global Corruption Barometer in 2016 places Romania first in the EU in terms of the percentage of households that have paid a bribe-29\%, with Lithuania a distant second at 25\% [61]. The Bertelsmann Foundation's Sustainable Governance Indicators for 2018, particularly the one measuring democratic quality and rule of law, including corruption prevention, shows that Romania is third to last in the EU, ahead of only Poland and Hungary, respectively [62]. Freedom House's Nations in Transit report paints a similar story, with corruption scores of between 4 and 3.75 between 2009 and 2018; in 2018, only Bulgaria, Croatia, and Hungary fared worse than Romania in this aspect [63]. The World Bank's Worldwide Governance Indicators (WGI) dataset on control of corruption also shows Romania third to last in the entire EU, followed only by Greece and Bulgaria [64].

More data are available from EU-led research. The October 2017 Flash Eurobarometer shows that $85 \%$ of business people consider corruption to be a problem in Romania, versus $37 \%$ as the average across all 28 member states [65]. 96\% of businesses surveyed consider the issue to be widespread in Romania, particularly bribes, kickbacks, and nepotism in public institutions. At the general public level, corruption is seen as widespread by $80 \%$ of interviewed subjects; $46 \%$ of all subjects consider that corruption has increased over the past three years, while $37 \%$ believe it has stayed the same. Only $10 \%$ believe it has decreased. $68 \%$ of all respondents believe that corruption affects their daily life, compared to only $25 \%$ as the EU28 average. Interestingly, $26 \%$ of surveyed Romanians believe that corruption is widespread in private companies versus $40 \%$ as the EU 28 average; along with perceptions of corruption in banks and financial institutions (26\% in Romania vs. 33\% EU28 average), this is the only sector where Romania scores better than the EU28 average, which suggests that Romanians may see private companies as a less critical source of corruption compared to the public sector. At the same time, when probed further, $80 \%$ of surveyed Romanians "totally agree" or "tend to agree" with the statement that "corruption is part of the business culture in Romania" [66].

Importantly, the data mentioned above do not refer to B2B corruption specifically. Certainly, one can speculate that business people who consider corruption to be widespread in Romania may have encountered it in transactions between companies as well. The $26 \%$ of surveyed Romanians who believe corruption is widespread in private companies may refer to $\mathrm{B} 2 \mathrm{~B}$ transactions, but it is more likely that they actually reference business-to-government corruption, which is a lot more visible in the media, particularly when it comes to real estate and infrastructure works, as well as the health sector. This is in no way unique to Romania. In his 2003 study, Argandoña makes precisely this point: "the cases of corruption reported by the media tend to almost always involve a private party that pays or promises to pay money to a public party" [7] (p. 253).

Unfortunately, as of June 2019, there are no surveys or other types of studies focused on Romania's B2B corruption specifically. The current research is indeed a first of its kind, and, as explained below, it focuses on C-level managers, who are likely to know more about the prevalence and mechanisms of B2B corruption. At the level of the general population, until recently, there had been no media scandals or major B2B corruption cases reported, so it was reasonable to presume that the phenomenon remained largely unknown or ignored by most Romanian citizens. This changed in August 2019, when public opinion was shocked to hear that the head of one of the largest corporations in the country was under investigation for B2B corruption charges for kickbacks requested in previous years, totaling over 800.000 euros. This high-profile case has not only helped inform the Romanian business community and broader society regarding the risks and costs of B2B corruption, but it has also brought new attention to the topic, with more and louder voices calling for common standards and clear solutions to combat this phenomenon. It is clear that more empirical research, especially on a case like Romania, widely perceived as a corrupt country and understudied with respect to B2B corruption, will help not only to understand this phenomenon, but also to provide solutions to fight against it. As an exploratory 
research, the current study starts from the findings of the existing literature and provides-albeit at a preliminary level—answers to three research questions.

Q1. What determinants favor B2B corruption in Romania?

Q2. Is there a standardized understanding among Romanian business leaders on what constitutes B2B corruption?

$Q 2 a$. What forms does B2B corruption take?

$Q 2 b$. Does the probability to face B2B corruption forms increase with professional experience (i.e., number of years since entered the labor force)?

Q3. Do Romanian business leaders want to play a role in combating B2B corruption?

Q3a. What kind of solutions do Romanian Business leaders prefer when it comes to combating B2B corruption?

\section{Methodology}

After reviewing the literature on this topic, the first step of the current research was to design a questionnaire. The questions included are similar to those featured in similar surveys, such as the 2017 Flash Eurobarometer on Business Attitudes toward Corruption in the EU [58], Transparency International's 2011 Putting Corruption out of Business [49], and, most importantly, the so-called PrivaCor study of the Danish and Estonian business environment [55]. Of these, the last one is the only one to concentrate specifically on the issue of B2B corruption, including forms and frequency, excuses, consequences, and potential measures against this phenomenon.

Based on these sources, the second step was to deploy the draft survey to be discussed in in a focus group of ten entrepreneurs in Bucharest, Romania. Given the sensitivity of the topic addressed, focus group members were selected based on personal connections, including people who would feel comfortable sharing their experiences of B2B corruption in Romania and providing feedback on the proposed survey questionnaire. These ten members of the focus group were then excluded from the sample that filled out the final version of the survey, as to ensure equal treatment among all respondents in the sample. One of the key insights emerging from the focus group was that Romanian entrepreneurs are generally unwilling to discuss the very delicate topic of B2B corruption. Some fear reprisals in terms of potential legal actions, others are weary of reputational costs. Time and again, focus group participants would introduce their sentences with "between us" and "let me say something that should not leave this table." On more than one occasion, participants verified with the focus group moderator the rules of the engagement, including full confidentiality.

In the third phase, upon finalization of the survey, the study used an online platform to distribute the questions and collect answers. The link ensured the full discretion of subjects' inputs and required unique answers. It was clear from the focus group discussions that survey participants would be hard to find because of privacy, legal, and reputational concerns. As such, a nonprobability sampling method was used, whereby initially the researcher chose a number of 15 "trusted respondents." Specifically, these 15 people fulfilled several basic criteria: (i) active in the business world as entrepreneurs or employees of various companies, in a diverse array of sectors (financial, services, legal, industrial, IT, manufacturing, energy, agriculture, etc.), both men and women (10 men and 5 women), at various ages and levels of professional experience, from both Romanian and foreign-owned companies, and from firms of different sizes; (ii) occupying leadership positions (C-level); and (iii) benefitting from a trust-based relationship with the researcher [67], which helped create a safe environment for sharing actual perceptions of and experiences with B2B corruption. Importantly, the likelihood of engagement in B2B corruption (e.g., selecting respondents from particular business sectors more prone to this phenomenon) was not a selection criterion.

To increase the sample further, the research used the snowball technique, also known as chain referral sampling. Scholars have identified this method as one of the most effective in exploring hard to reach or hidden target populations [68]. Each of the initial participants was asked to recommend the survey to a maximum of five other business contacts that would meet the three criteria noted above, and then those participants were asked to recommend the survey to three other business people, 
and so on. The sample reached 120 responses within two months of collecting answers. The arguments in favor of using the snowball sampling method are multiple-fold: for one, the target population is hard to reach because of the sensitive topic addressed and because of the professional status of the respondents (i.e., top managers with very limited time resources); second, trust is vital to ensure that accurate answers to the questions are collected and that the research is seen as a credible and good-faith effort; third, it is relatively quick and efficient to expand the sample and get a wide-array of answers precisely because the research leverages direct and indirect social ties, ensuring a higher degree of subjects' involvement and cooperation.

Evidently, there are also disadvantages and limitations related to using this research method. By definition, it is not representative, as subjects are not selected randomly from the entire population of Romanian businesses. The final sample of respondents is based on personal connections. While the so-called snowball starts with a group of people selected independently of their potential knowledge of and experience with $\mathrm{B} 2 \mathrm{~B}$ corruption, they may-once they fill out the survey and are asked to send it further-inherently think of others in their network who match their own convictions and attitudes. The research took great care in presenting the survey as an assessment of Romania's business environment, without any references to B2B corruption in the title or in the introductory questions. Still, because most questions do touch on this sensitive issue, it is possible that the prevalence and effects of $\mathrm{B} 2 \mathrm{~B}$ corruption in Romania are overstated. It is also possible that people with larger and stronger networks are over-represented in the sample. The research tried to mitigate this by limiting the number of total referrals to five business contacts for each of the respondents. As with any nonprobability research technique, generalizations of the current research results are to be treated with caution.

As a baseline study, the current research provides a first-of-a-kind glance into the phenomenon of B2B corruption in Romania. While recognizing the research method's limitations, it argues that the nature of the topic explored in a very sensitive environment warrants the use of the snowball sampling method. As an alternative, the research considered probability sampling for the entire population of businesses in Romania, using a publicly available database [69] and sending the survey to randomly selected subjects. However, this would have still entailed major response, coverage, and participation biases. It is unlikely that top managers would have taken the time required to answer the questions entirely and truthfully, particularly in the absence of a trust-based relationship with the researcher or with the referrer. In fact, most surveys of corruption perceptions-and all surveys that go into Transparency International's CPI scores-are not based on representative samples, but rather on expert and businesspeople assessments [70].

\section{Data}

The resulting sample of subjects is very diverse, though, as noted before, it should not be considered representative for the entirety of businesses in Romania [71]. The average years of work experience is 15 , with $75 \%$ of respondents between 30 and 50 years old, $14 \%$ under 30 , and $10 \%$ between 51 and 65 . Seventy percent of surveyed business people were male and $30 \%$ were women. The best-represented sectors in the sample were: general services (19\%); finance and banking $(14 \%)$; IT (13.2\%); legal, business, and real-estate services (9.9\%). In terms of company size, the sample was split evenly: $30.6 \%$ small companies ( $0-5$ employees), 35.5\% medium-sized (6-99 employees), and $33.9 \%$ large companies (over 100 employees). $61.3 \%$ had $100 \%$ Romanian capital, $24.4 \%$ were entirely foreign owned, and $14.3 \%$ were mixed. $18.3 \%$ of companies represented in the sample were publicly listed. As for the number of years since founded or first present on the local market, the sample tends to include companies with many years of experience in Romania: $27.3 \%$ over 20 years, $31.4 \%$ between 11 and 20 years, and $13.2 \%$ between 6 and 10 years. Less than $6 \%$ of respondents were from new businesses with under one year of presence on the local market. Last but not least, $64 \%$ of the sample included business-to-business companies, $27.3 \%$ business-to-consumer firms, and $8.3 \%$ business-to-government enterprises (businesses where public entities are the main customers). 


\section{Findings}

\subsection{Corruption Perceptions among Business Leaders}

\section{Q1. What determinants favor B2B corruption in Romania?}

Three major determinants emerge as favoring B2B corruption in Romania, supporting the findings from the existing literature. One is the perception of a high level of general corruption in the country. Businesses are embedded in society, therefore any distortion in society affects companies. Businesses surveyed as part of this research perceive corruption as a major issue in the Romanian context. $47.5 \%$ of respondents see corruption as a "very serious" problem in doing business, and an additional $20.8 \%$ qualify it as "a serious" problem. This result is consistent with the results of other studies [58], and suggests that surveyed Romanian business leaders perceive corruption as an important challenge in their business pursuit. When asked specifically about the prevalence of B2B corruption, $37 \%$ of respondents described it as "high," with an additional $49.6 \%$ qualifying it as "average."

Another determinant is the malfunction of institutions, mostly those that are responsible with the fight against corruption. Despite the fact that National Anti-Corruption Directorate, under the mandate of Laura Codruta Kovesi (the new European Chef Prosecutor) registered important victories against some big public corruption cases, the phenomenon is too widespread and institutions generally do not show the same commitment to anticorruption. As one of the respondents commented: " ... if the Romanian Parliament protects its corrupt members, what do you expect from the rest of the institutions, led by the sons or nephews of those accused by corruption?" Of the entire sample, only $1.7 \%$ believe that anticorruption institutions function "very well," while 16.5\% describe their functioning as "very poor" and 31.2\% as "relatively poor." This suggests that B2B corruption is a subset of corruption-related experiences in the work of surveyed Romanian business leaders.

Mentality was identified as the third determinant of B2B corruption in the eyes of Romanian business leaders. Romania is the country with generalized corruption: bribery, gifts, and nepotism are encountered at all levels of society. "If you are taught from your childhood that a gift will open any door and will solve any problem, you will behave in this way for your entire life," commented one business leader. "Petty corruption is a way of life in Romania. It is in our brain, in our communist heritage. Which was that dictum from the communism? If you don't steal from the factory, it means you steal from your family. This is the case!" As another respondent commented: "if you know the right person, you may have whatever you want, in a public entity as much as in a private entity: a job, a favor, a contract ..." "However, some respondents considered B2B corruption less spread than public corruption. In the words of one respondent to the survey: "I have seen corruption happening in transactions between private companies and the Romanian state, not between businesses." The General Director of a small service provider concurred: "B2B corruption, compared to public corruption, is insignificant."

But other business leaders noted that the business environment is a mirror of the wider society, and hence as corrupt as that society. In the words of one business owner of a small local manufacturing company, "private companies are as corrupt as state institutions." He added: "If you are lucky enough to deal directly with a company's owner, there is no way that corruption is allowed. If you deal with managers, however, with some rare exceptions, you can kiss your sales goodbye [unless you bribe them]." Another entrepreneur said that "corruption is deeply engrained in the mentality of business people in Romania." Similar views strengthened the view that corruption is widespread, and all the options provided by the survey's question correspond to B2B corruption examples. Many representatives of multinational institutions were in agreement with this perspective-a likely reflection of stronger internal accountability mechanisms.

At the same time, a Romanian business owner argued that in his experience "multinationals pay the biggest bribes and ruin [the market] for everyone else." A recent investigation conducted by National Anti-Corruption Directorate has started criminal prosecution procedures against the director of a large multinational IT company for bribe taking (EUR 869,413) in eight cases during 
2009-2013 from the representatives of another local IT company in exchange of advantageous contracts. The media hailed this case as the first major B2B corruption scandal in the country.

\subsection{Recognizing B2B Corruption}

Q2. Is there a standardized understanding among Romanian business leaders on what constitutes B2B corruption? Q2a. What forms does B2B corruption take?

Most respondents to the survey have encountered different forms of corruption in their professional careers, as shown in Figure 1 below. When probed specifically about B2B relations, the numbers decrease, sometimes significantly, particularly in the case of very serious offenses: conflicts of interest ( $80 \%$ generally vs. $55 \%$ in B2B), bribing (67.5\% generally vs. $39.1 \%$ in B2B), fraud ( $62 \%$ vs. $43.3 \%)$, kickbacks ( $85 \%$ vs. $71.6 \%)$.

The data also allow for a rough comparison with other countries, specifically Denmark and Estonia from the 2016 PrivaCor study [48], while keeping in mind that the two research efforts have different samples in terms of size and representation. Romanian managers surveyed tend to be more exposed to corrupt practices: kickbacks (72\% in Romania vs. $46 \%$ in Estonia and 34\% in Denmark), conflicts of interest (55\% in Romania vs. $49 \%$ in Estonia and 38\% in Denmark), bribery (39\% in Romania vs. $29 \%$ in Estonia and $21 \%$ in Denmark), and fraud (43\% in Romania vs. $22 \%$ in Estonia and $15 \%$ in Denmark). This is to be expected, taking into account overall corruption perception data, Transparency International's CPI, which show that Denmark is the least corrupt country in the world with a score of 88. Estonia ranks 18 th with a score of 73 , and Romania ranks 61 st with a score of only 47 [11]. What the current study shows is that managers' experiences with corruption tend to mirror general perceptions of corruption in society at large.

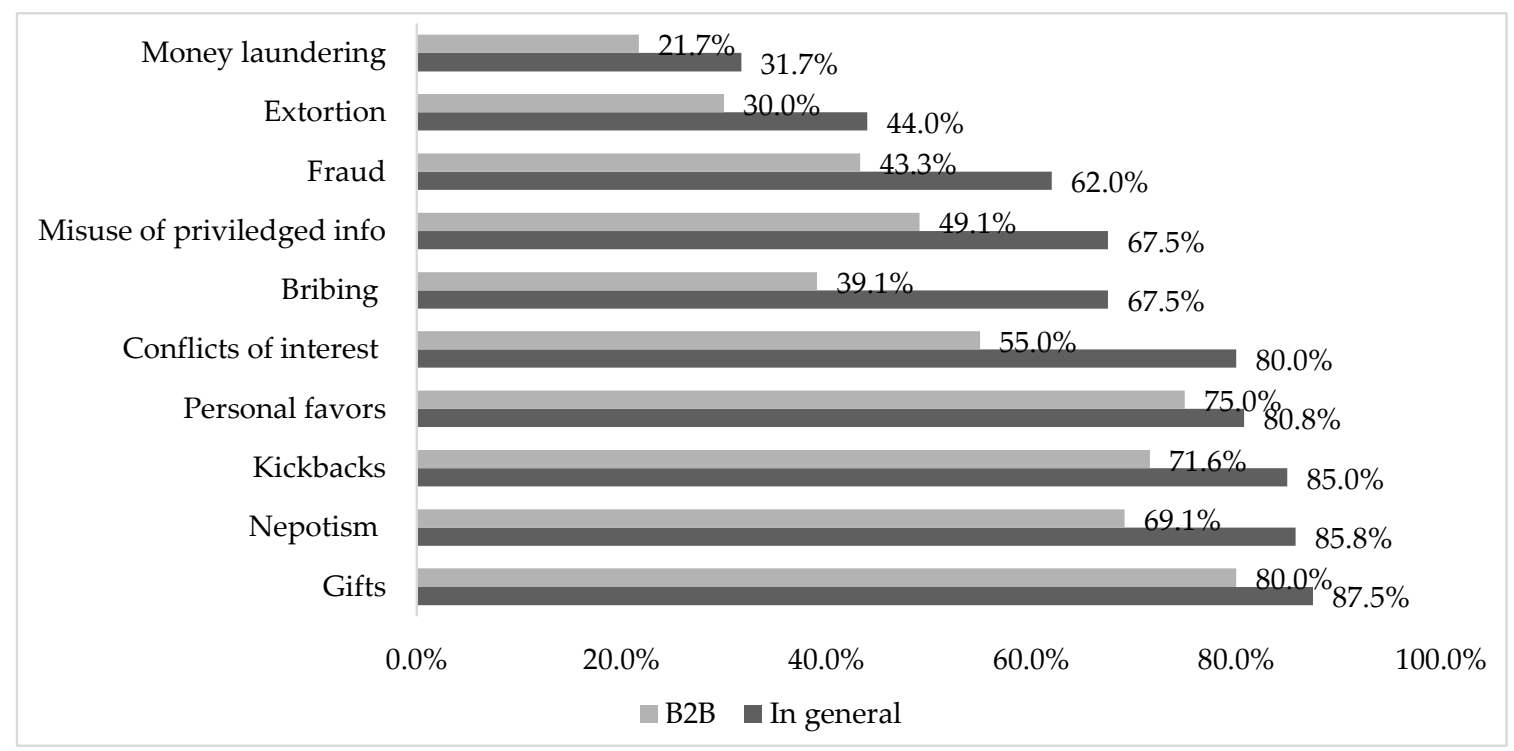

Figure 1. Prevalence of various forms of corruption (respondents selected all those encountered).

The survey also asked respondents to note whether particular transactions qualify as corruption in relations between private companies. The results prove that views are mixed, particularly around kickbacks (only $42.5 \%$ believe it is a form of B2B corruption), gifts (43.3\%), and personal favors $(53.3 \%)$. There is a lot more consensus when it comes to serious offenses like bribing (95\% identify it as corruption), extortion (95\%), money laundering (92.5\%), and fraud $(90.8 \%)$.

Qualitative answers provided to the last open-ended question of the survey-“Do you have any other comment related to private corruption in Romania, particularly B2B corruption?"- -help explain the different outcomes in recognizing B2B corruption forms. On the one hand, some respondents argued against classifying certain transactions between companies as B2B corruption. One banker 
noted: "Why should nepotism be corruption? Are family businesses by definition corrupt?" She added: "Gifts should not count as corruption if they are purely symbolical. They are part of our culture as atenții-some flowers, a diary, a box of chocolates, a small corporate basket, etc." Another respondent, a small business owner, put it bluntly: "Nobody is going to tell me how to run my business. In my company I can hire my mother if I so please, accept whatever gifts or commissions I am offered." For his part, the country manager of a multinational company noted that "there are clear rules and caps on gifts of EUR 25-30, and kickbacks are generally stipulated in contracts and have nothing to do with bribery." Finally, the president of a health company argued along these lines: "Corruption may breach norms, but it is not a crime. Honesty is not a moral duty, but a choice, for most companies."

Ultimately, much like beauty, corruption is in the eye of the beholder. Perceptions are inherently biased and vary depending on each respondent's personal experience. In general, business owners themselves tend to be much more flexible in their views on B2B corruption acts versus business as usual, while employees_-particularly of large companies—have the strictest standards, qualifying even grey-zone practices like favors, gifts, and kickbacks as corruption. This provides an answer to this study's question: indeed, Romanian business leaders have different levels of understanding of what constitutes B2B corruption; some forms of B2B corruptions are widely recognized as such (bribery, extortion or fraud); others induce more controversies (e.g., personal favors or gifts). This confirms earlier studies' findings [42] regarding the lack of a standardized understanding of the phenomenon. See Figure 2.

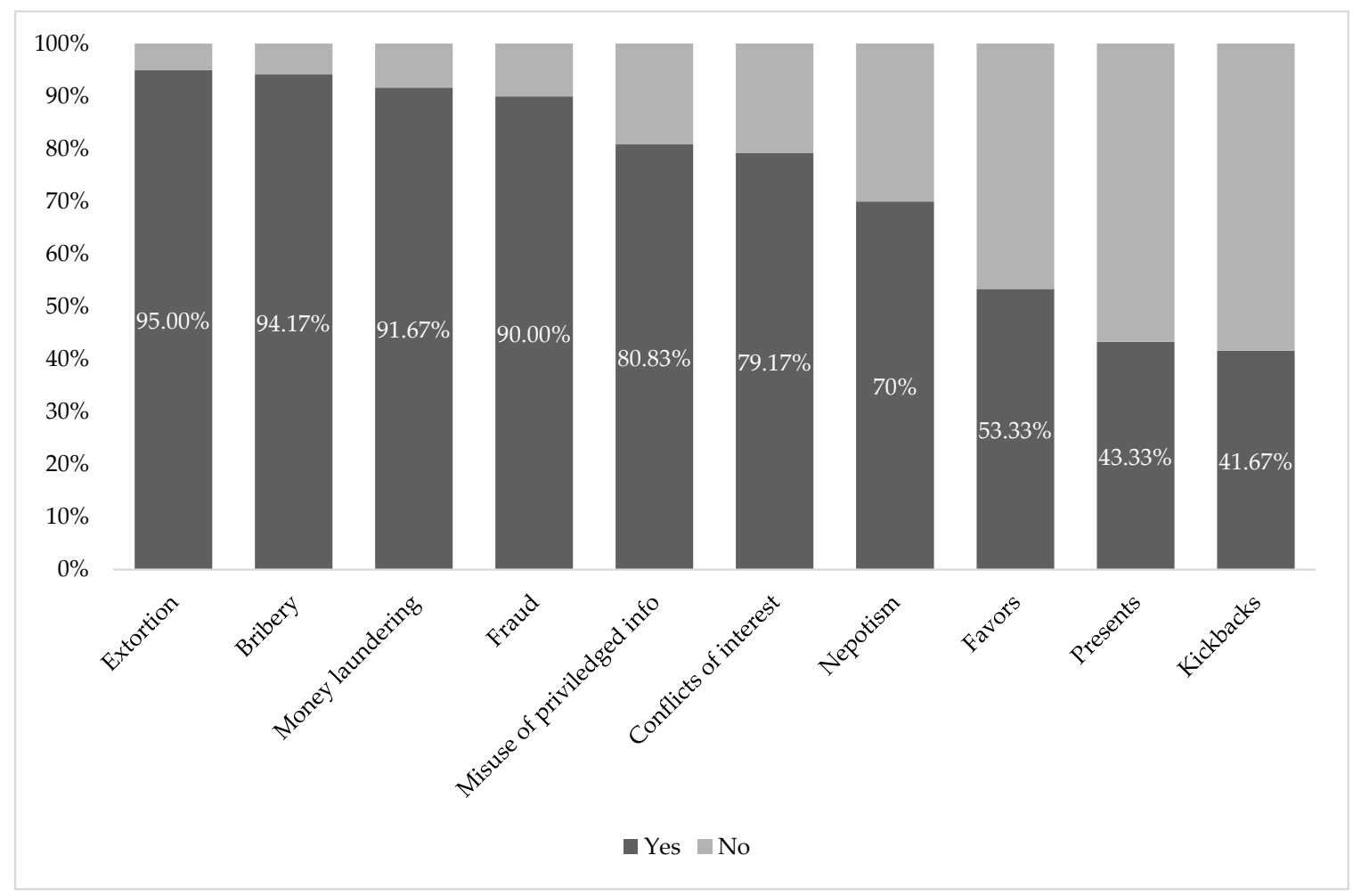

Figure 2. Percentage of survey respondents identifying different B2B transactions as corruption.

Q2b. Does the probability to face B2B corruption forms increase with professional experience (i.e., number of years since entered the labor force)?

Cramer's V correlations display weak to medium correlations $(p<0.01$ and $p<0.05)$ [71] between work experience and the probability to encounter certain forms of corruption (favors and nepotism) (see Table 1 and Appendix B below). 
Table 1. Cramer's V correlation between work experience and forms of B2B corruption.

\begin{tabular}{cccc}
\hline Variable 1 & Variable 2 & Strength of Correlation & Significance \\
\hline Favors & Work experience & Weak & Sig $<0.05$ \\
Nepotism & Work experience & Medium & Sig $<0.01$ \\
\hline \multicolumn{4}{c}{ Source: authors' calculations. }
\end{tabular}

This may be explained by the intuitive fact that someone working for a longer period of time acquires more information about the firm, business partners, and employees' behavior and practices, including B2B corruption. An older, more experienced employee likely enjoys a higher level of trust in relations developed both within the firm and between firms. This trust goes in both directions: toward ethical actions and toward corrupt behavior. As one of the respondents commented, " ... you will find out the exact person you have to talk with in order to solve the problem, an experienced person, anointed with all the ointments. (Translation of the Romanian expression "uns cu toate alifiile", which usually indicates a person who knows everything and knows what to do in a specific circumstance (a sort of gate keeper). They will tell you what to do, whom to pay, how much to pay, in a very confidential way." At the same time, there was no correlation found between work experience and the probability to encounter the other forms of corruption (aside from nepotism and personal favors).

\subsection{The Role of Businesses in Combating B2B Corruption. Internal and External Solutions for Preventing B2B Corruption}

\section{Q3. Do Romanian business leaders want to play any role in combating B2B corruption?}

When asked to identify the main barrier against combating corruption in the private sector, nearly half of all respondents ( $47.1 \%)$ put the blame on the "high prevalence of unethical behavior in society." $21.5 \%$ noted that the main barrier is that corruption is not legally punished. Others, however, were more inclined to identify the private sector itself as the main barrier against combating corruption: $19.8 \%$ noted that "corruption is generally accepted by the Romanian private sector" and $9.1 \%$ said that "companies do not take this problem seriously." When further asked whether their company had a moral duty to fight against corruption, the vast majority of business leaders surveyed said "yes" (73.6\%), with only 6.6\% responding "no" and 19.8\% selecting the "Do not know / cannot respond" option.

The survey also asked about what managers in each respondent's network would do in various circumstances: whether they would get actively involved in combating corruption ( $60 \%$ said yes); whether they would report an incident that involved corruption (59\% said yes); and whether they would support their colleagues if they fought against corruption (70.8\% said yes). Overall, the results are encouraging and indicate that Romanian business leaders generally want to play a positive role in combating B2B corruption. This is evident in the fact that almost three quarters of surveyed respondents believe that fighting against corruption is their moral obligation, as well as in the wide recognition of corruption's profoundly damaging consequences.

The survey further replicated a question from the PrivaCor study in the Romanian context, asking subjects to identify the main consequences of corruption in the private sector. Interestingly, Romanian managers appear very concerned about loss of business network in terms of access to suppliers and clients (75.2\% vs. only 38.7\% in Denmark and 34.5\% in Estonia). Romanians also seem more concerned about financial loss compared to both Danish and Estonian business leaders (61.2\% vs. $53.3 \%$ in Denmark and $47.4 \%$ in Estonia), but less concerned about the consequences on their careers, at least compared to Danish managers (53.7\% vs. 63.8\%). See Figure 3. 


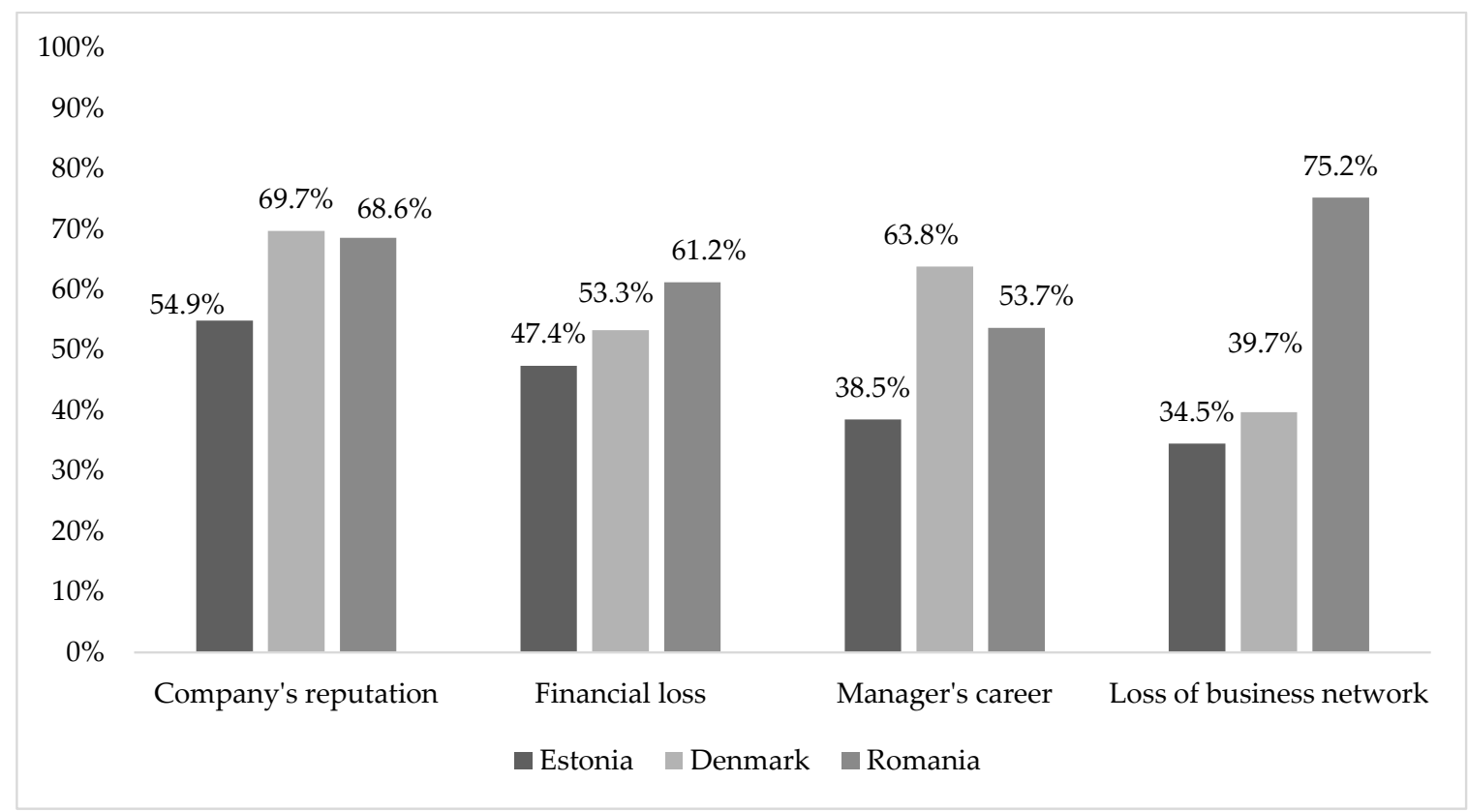

Figure 3. Perceptions of corruption consequences for Romania $(n=120)$ versus* Denmark and Estonia (PrivaCor study, $\mathrm{n}=500$ for each country). ${ }^{*}$ Note: As before, samples and sampling methods are different between the current research and the PrivaCor study. Comparisons are not meant to be perfect. Rather, the data for Denmark and Estonia serve as preliminary reference points to be verified by further research of the Romanian context.

The survey of Romanian managers also asked subjects what they would do if they witnessed corruption acts within their company. Again, results can be compared to data from Estonia and Denmark. While the first option in all three countries is to tell management or other board members, the rest of the hierarchy of reactions differs substantially. For instance, as shown in Table 2, Romanians would rather call an anonymous hotline compared to their counterparts (31.7\% of Romanian managers surveyed highly agreed with this option vs. only $8.3 \%$ in Estonia and $26.4 \%$ in Denmark). This reflects arguably higher fears of reprisals and weaker overall protection for whistleblowers, i.e., those individuals who reveal or confess to corruption acts. Along the same lines, in terms of going to the police the response rate is similar between Romania and Estonia, and a lot lower than in Denmark, possibly reflecting a lower level of trust in the police. By contrast, $12.5 \%$ of Romanian managers would go to the press versus much smaller proportions in Estonia (1.5\%) and Denmark (4.9\%). This may signal that Romanians are more comfortable with media scrutiny; indeed, in recent years, journalists have covered an impressive number of corruption cases, and public shaming is often seen as part of a rightful punishment. Finally, virtually no respondents in Romania would "do nothing," while almost $11 \%$ of Danes would ignore the situation.

At the same time, expressed preferences for handling corruption cases discreetly, as opposed to going to the press or the police, are perfectly reasonable. Private businesses fear repercussions from the state or other businesses, as well as potentially irreparable damages to their reputation in case corruption scandals break out publicly. 
Table 2. Romanian vs. Estonian vs. Danish managers' responses in case of witnessing a corruption act.

\begin{tabular}{|c|c|c|c|c|c|c|}
\hline \multirow{2}{*}{$\begin{array}{c}\text { If You Witnessed a Corruption Act } \\
\text { within Your Company, Who Will } \\
\text { You Report It To? }\end{array}$} & \multicolumn{2}{|c|}{$\begin{array}{l}\text { Romania* } \\
\text { Current Study } \\
\quad n=120\end{array}$} & \multicolumn{2}{|c|}{$\begin{array}{c}\text { Estonia* } \\
\text { PrivaCor Study } \\
n=500\end{array}$} & \multicolumn{2}{|c|}{$\begin{array}{c}\text { Denmark }^{*} \\
\text { PrivaCor Study } \\
n=500\end{array}$} \\
\hline & Rank & \% Highly Agree & Rank & \% Highly Agree & Rank & $\%$ Highly Agree \\
\hline $\begin{array}{l}\text {... management or other members } \\
\text { of the board }\end{array}$ & 1 & 78.3 & 1 & 92.3 & 1 & 89.4 \\
\hline ... talk with involved colleague(s) & 2 & 45.8 & 2 & 48.1 & 4 & 42.7 \\
\hline ... contact an anonymous hotline & 3 & 31.7 & 5 & 8.3 & 5 & 26.4 \\
\hline ... talk at home/with friends & 4 & 25 & 3 & 19.4 & 2 & 55.2 \\
\hline ... go to the police & 5 & 16.7 & 4 & 15.8 & 3 & 49.6 \\
\hline$\ldots$ go to the press & 6 & 12.5 & 7 & 1.5 & 7 & 4.9 \\
\hline ... do nothing & 7 & 0.08 & 6 & 3.0 & 6 & 10.9 \\
\hline
\end{tabular}

* Note: The Romanian survey results are not perfectly comparable with the PrivaCor survey data for Estonia and Denmark. The samples and sampling methodologies are different, as is the timing of the measurements. Moreover, the option of "talk with other colleagues" was excluded from the analysis, as it was not featured in the Romanian survey. This should not change the other data, however, as respondents reacted to each option separately. The data are shown side by side to provide rough reference points, not as a basis for running regressions or other types of statistical comparisons.

As mentioned before, Romanian business leaders would disclose B2B corruption if they witness it. Forms of disclosure vary from "informing management or other members of the board" to "talking with involved colleague(s)," "contacting an anonymous hotline," "talking at home/with friends," "going to the police," and "going to the press" (see Table 1). Running Mann-Whitney U-tests, the results showed a difference in the preferred forms of disclosure depending on structure of the capital $(p<0.1)$. Thus, there is a higher preference among respondents working for foreign companies to be more open to notify management about corruption than those working for Romanian companies (see Tables 3 and 4). The results should be treated with caution because of their significance level.

This may be explained by the organizational culture and management attitude toward corruption, as well as cultural factors that determine corruption [72-74] and the way people react to it. Foreign companies, mostly those from a Western culture, advertise internally and externally their zero-tolerance attitude toward corruption. At the same time, respondents working for Romanian companies tend to be more open to talking to their colleagues about corruption than those working for foreign companies or mixed companies $(p<0.05)$ (see Tables $5-8$ ). This may reflect an extension of the general attitude existing in Romania, whereby corruption is one of main issues discussed in society. It can be also a result of a "more familiar place": Romanian companies, Romanian colleagues, the same culture based on shared values and a feeling of belonging.

Table 3. Ranks-notify management and type of ownership (Romanian vs. foreign).

\begin{tabular}{ccccc}
\hline & Equity & N & Mean Rank & Sum of Ranks \\
\hline \multirow{2}{*}{ Notify } & Romanian & 74 & 49.66 & 3674.50 \\
management & Foreign & 29 & 57.98 & 1681.50 \\
& Total & 103 & & \\
\hline
\end{tabular}

Table 4. Test Statistics ${ }^{\text {a }}$-notify management and type of ownership (Romanian vs. foreign).

\begin{tabular}{cc}
\hline & Notify Management \\
\hline Mann-Whitney U & 899.500 \\
Wilcoxon W & 3674.500 \\
Z & -1.782 \\
Asymp. Sig. (2-tailed) & 0.075 \\
\hline \multicolumn{2}{c}{${ }^{a}$ Grouping Variable: Equity. }
\end{tabular}


Table 5. Ranks—talk to colleagues and type of ownership (Romanian vs. foreign).

\begin{tabular}{lcccc}
\hline & Equity & N & Mean Rank & Sum of Ranks \\
\hline \multirow{3}{*}{ Talk to colleagues } & Romanian & 74 & 55.46 & 4104.00 \\
& Foreign & 29 & 43.17 & 1252.00 \\
& Total & 103 & & \\
\hline
\end{tabular}

Table 6. Test Statistics ${ }^{\text {a }}$ - talk to colleagues and type of ownership (Romanian vs. foreign).

\begin{tabular}{cc}
\hline & Talk to Colleagues \\
\hline Mann-Whitney U & 817.000 \\
Wilcoxon W & 1252.000 \\
Z & -2.034 \\
Asymp. Sig. (2-tailed) & 0.042 \\
\hline \multicolumn{2}{c}{${ }^{a}$ Grouping Variable: Equity. }
\end{tabular}

Table 7. Ranks—talk to colleagues and type of ownership (Romanian vs. mixed).

\begin{tabular}{lcccc}
\hline & Equity & N & Mean Rank & Sum of Ranks \\
\hline \multirow{3}{*}{ Talk to colleagues } & Romanian & 74 & 49.00 & 3626.00 \\
& Mixed & 17 & 32.94 & 560.00 \\
& Total & 91 & & \\
\hline
\end{tabular}

Table 8. Test Statistics ${ }^{\text {a }}$-talk to colleagues and type of ownership (Romanian vs. mixed).

\begin{tabular}{cc}
\hline & Talk to Colleagues \\
\hline Mann-Whitney U & 407.000 \\
Wilcoxon W & 560.000 \\
Z & -2.453 \\
Asymp. Sig. (2-tailed) & 0.014 \\
\hline \multicolumn{2}{c}{${ }^{a}$ Grouping Variable: Equity. }
\end{tabular}

Q3a. What kind of solutions do Romanian Business leaders prefer when it comes to combating B2b corruption?

Last but not least, Romanian managers were asked to evaluate different internal and external solutions for preventing corruption in the business sector. In terms of measures that the companies themselves could adopt, the following hierarchy emerged, based on the percentage of "high agreement" with each option: anti-corruption standards in each company (70\% highly agreed); collective business initiatives against corruption (66.7\%); Corporate Social Responsibility agenda including anticorruption measures (62.5\%); internal auditing programs (59.1\%); and due diligence on partners in the supply chain $(55.8 \%)$. As for external measures, the order of preferred options is as follows: national anticorruption legislation (73.3\% highly agreed); multistakeholder initiatives across business, public, and nonprofit sectors (70\%); supporting investigative journalism (61.7\%); and international treaties and conventions (56.7\%).

Once again, the high proportion of subjects who agree with aforementioned solutions against B2B corruption is good news for the future of Romania's business environment. Correspondingly, the level of disagreement with proposed measures is extremely low-under $9 \%$-for each of the options. Romanian business leaders support both internal and external solutions for reducing B2B corruption. Indeed, these are not mutually exclusive options. Romania's government can strengthen B2B anticorruption legislation and encourage multistakeholder initiatives, while individual businesses can adopt their own anticorruption policies and join Clean Business Coalitions [75]. An interesting finding is related to the role of media as an anticorruption measure. This is explained by the context of Romania, as media is one of the main social actors involved in disclosing corruption. 


\section{Conclusions}

Through the results presented above, this study has shown B2B corruption is real and widespread in the Romanian context. According to the views expressed by surveyed Romanian business leaders, B2B corruption is determined by the general context, characterized as corrupt, malfunctions of the institutions, and the general mentality tolerant to various form of corruption. Businesses are embedded in society in such a manner that cannot be separated from other parts of the system. If the system is corrupt, all its components are thereby touched by corruption. If the institutions do not function properly, then damaging, unfair practices spread among the system's actors. If the general mentality is tolerant to corruption, people are generally reluctant to take a stand against corruption. In a safe, trust-based environment, ensured through the snowball sampling method, most business leaders admit the profoundly damaging effects of B2B corruption. They express their willingness to fight against it, both at the level of each company and by supporting broader policy and legal changes in the Romanian society. Because the issue has been largely ignored to date, there are clear shortcomings that will need to be addressed, most notably the different levels of understanding among business leaders of what B2B corruption is, how it affects their enterprise, and what they can do about it. That said, there is plenty of willingness, at least as reflected in the vast majority of responses to the survey, to become educated on the topic and bring a positive contribution to efforts addressing B2B corruption.

As noted in the methodology section, the current study is exploratory, and entails several key limitations. The nonprobability sampling means that reliable regressions cannot be run, so there can be no high degree of certainty regarding, for instance, the relationship between attitudes toward B2B corruption and a range of independent variables, including company sector, managers' years of experience, gender, etc. In other words, the results cannot be generalized to the entire world of business people active in Romania. At the same time, the data are not fully comparable to other studies' results, as mentioned before. Third, there are inherent limitations in studying B2B corruption with the help of surveys, including the probable tendency to conceal certain aspects for fear of legal or reputational consequences.

Despite these shortcomings, this baseline study remains the first of its kind, opening up opportunities for further inquiry into B2B corruption in the Romanian context and beyond. Potential future research questions worth answering include: Are emerging leaders, such as economics and business school students, equipped to recognize and address B2B corruption? What types of educational programs would be most efficient in explaining the phenomenon? How can the business community, together with other interested stakeholders, raise awareness regarding B2B corruption? What are some of the globally proven techniques to combat it? Why are some business leaders more likely than others to see fighting against B2B corruption as a moral duty? To answer these questions accurately, a mix of research techniques could be deployed, including both chain referral sampling and fully randomized — and representative — sampling of the entire universe of businesses operating in Romania.

\section{Implications of This Research}

There are multiple implications of the current findings. For one, the data show that corruption, including $\mathrm{B} 2 \mathrm{~B}$, is perceived as a challenge by the private sector in Romania, at least based on the vast majority of responses to the survey. Second, specialized programs are needed to inform and educate business leaders on B2B corruption specifically. For instance, the ISO 37001 certification for anti-bribery management systems claims to cover bribery "in the public, private, and not-for-profit sectors" [76]. Similar standards and certifications could be developed to counter other forms of B2B bribery, particularly those that are harder to recognize compared to blaring crimes like fraud and money laundering - e.g., kickbacks, nepotism, favors, etc. Third, recommended preventative measures, particularly those garnering high levels of support among surveyed business leaders, should be piloted, tested, improved, and replicated, along with continuous monitoring and evaluation (M\&E) systems to understand what is working best. 
Given the survey's results, albeit on a small, non-representative sample, there appear to be opportunities for sharing knowledge and best practices across businesses. Generally, larger companies, publicly listed ones, those with primarily foreign capital, and those present on the Romanian market for longer seem to be better equipped to understand and act against B2B corruption. Cross-pollination efforts could focus on finding and adopting the best auditing systems, procurement mechanisms, partner auditing programs, anticorruption regulations and whistleblower protections within each company, etc. Equally important, to support some of the needed external policy and legal reforms, interested businesses could join forces to speak with one voice against B2B corruption.

Ultimately, business leaders bear the responsibility of their decisions. One of the senior financial experts interviewed during the research process put everything in the following terms: "business-to-business corruption is in effect corruption between two individuals, one in each business, both guilty for what is happening; one for offering, the other for accepting." Beyond norms, procedures, codes of ethics, and clean business coalitions, B2B corruption is all about individuals engaging in an immoral, illegal exchange. This is why this type of research is of vital importance: it uncovers individual perceptions, biases, and motivations, focusing on the critical links in the chain-i.e., the business people who decide whether to add to or reduce B2B corruption. They can choose to ignore or even contribute to B2B corruption, at significant personal, company-wide, and societal cost, at least in the long run, or they choose to fight against it. With the growing importance of the private sector globally, the future is truly in their hands.

Author Contributions: Conceptualization, S.I.B. and R.M.Z.; Data curation, S.I.B. and R.M.Z.; Formal analysis, S.I.B. and R.M.Z.; Methodology, S.I.B. and R.M.Z.; Resources, S.I.B.; Supervision, R.M.Z.; Visualization, S.I.B.; Writing-original draft, S.I.B.; Writing—review \& editing, R.M.Z.

Funding: This research received no external funding.

Acknowledgments: The authors would like to thank the anonymous reviewers and Professor Tudor Edu for their valuable comments and suggestions. Rodica Milena Zaharia is grateful for the discussions and thoughts shared through the work on CNCS - UEFISCDI, project "ReGrowEU - Advancing ground-breaking research in regional growth and development theories, through a resilience approach: towards a convergent, balanced and sustainable European Union."

Conflicts of Interest: The authors declare no conflict of interest.

\section{Appendix A. Survey Questionnaire}

\section{Introduction}

Thank you for agreeing to take part in this important assessment. This research project aims to evaluate corporate practices in Romania, particularly as reflected in business-to-business relations. Given the sensitive topics addressed, we pledge to respect the full confidentiality of your answers to this survey.

\section{Sample Data}

\section{Respondent}

1. Current position (level)

2. Previous experience (number of years of professional experience)

3. Age (under $30,30-50,51-65,65+$ )

4. Gender

\section{Company}

1. Company sector (banking and finance; real estate, business, and legal services; heavy manufacturing; arms, defense, and military; civilian aerospace; public works contracts and construction; information technology; consumer services; light manufacturing; mining; agriculture; fisheries; forestry; pharmaceuticals and healthcare; oil and gas; utilities; power generation and transmission; telecommunications and equipment; transportation and storage) 
2. Size-number of employees $(0-5,5-49,50-99,100+)$

3. Type of ownership (local, foreign, mixed)

4. Public listing on stock exchange (yes/no)

5. HQ location in (city, country)

6. Age of mother company and of company in Romania $(0-1,2-5,6-10,11-20,20+)$

7. Type of company (B2B, B2C, B2G)

\section{Questions}

(1) Do you consider the following to be a problem or not for your company when doing business in Romania? [For each, the respondent chose between: a very serious problem, a somewhat serious problem, not a very serious problem, not a problem at all, don't know/don't answer]

- Tax rates

- $\quad$ Fast-changing legislation and policies

- $\quad$ Complexity of administrative procedures

- $\quad$ Lack of means or procedures to recover debt from others

- $\quad$ Restrictive labor regulations

- $\quad$ Access to financing, including credits

- Inadequate infrastructure

- $\quad$ Patronage and nepotism

- Corruption

(2) In your professional career in Romania, which of the following have you encountered in general? What about specifically in business-to-business relationships? [may select multiple]

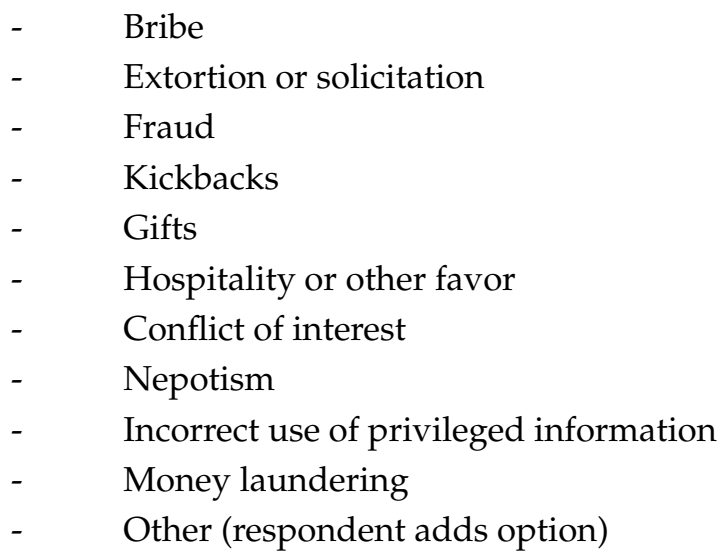

(3) Which of the following do you think counts as corruption in business-to-business relationships? [may select multiple]

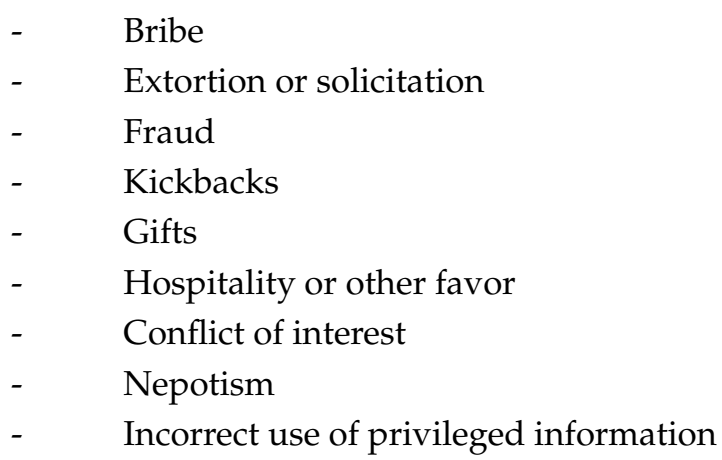


- $\quad$ Money laundering

- $\quad$ Other (respondent adds option)

(4) How would you characterize corruption levels in business-to-business relationships in Romania?

- $\quad$ High

- $\quad$ Average

- $\quad$ Low

(5) How well do you think Romania's anti-corruption laws and institutions function today?

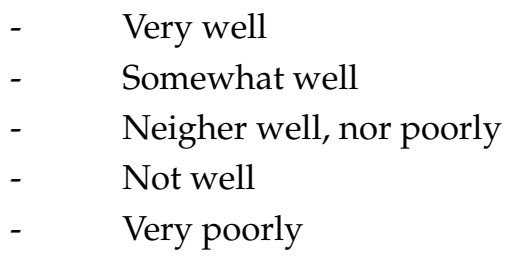

(6) Which of the following is the main barrier to stopping bribery and corruption in the private sector in this country?

- $\quad$ Corruption and bribery related crimes are not prosecuted

- $\quad$ Businesses do not take the issue seriously enough

- Unethical behavior is widespread

- Corruption is widely accepted as a fact of life

- $\quad$ Other

(7) My company has an ethical duty to fight corruption

- Yes

- $\quad$ No

- $\quad$ Don't know/don't answer

(8) Answer yes or no to the following statements regarding the managers you know:

- $\quad$ They would get involved in the fight against corruption

- $\quad$ They would report an incident with potential corruption acts

- $\quad$ They would support their colleagues if they fought against corruption

(9) Does your company have in place the following measures? [select all that apply]

- $\quad$ a code of ethics;

- $\quad$ an anti-corruption policy;

- $\quad$ regular staff training on anti-corruption;

- $\quad$ inclusion of corruption prevention in risk management strategy;

- $\quad$ measures in place to support potential whistleblowers;

- $\quad$ a prohibition on commissions or other types of facilitation payments

(10) What are the main consequences of corruption in Romania's private sector? [select all that apply]
- $\quad$ Company reputation
- $\quad$ Financial loss
- $\quad$ Staff careers
- $\quad$ Loss of business network 
(11) If you witness behavior that may be corrupt in your company, you would: [Respondents will be able to select for each option: strongly agree, agree, disagree, strongly disagree, don't know]

- $\quad$ Tell management or other members of the board

- $\quad$ Talk with that colleague

- $\quad$ Talk about it at home/with friends

- $\quad$ Go to the police

- Contact an anonymous hotline

- $\quad$ Go to the press

- $\quad$ Do nothing

(12) Do you feel the following internal measures your company can take are effective in addressing corruption in the private sector? [Respondents will be able to select for each option: strongly agree, agree, disagree, strongly disagree, don't know]

- Collective business initiatives against corruption

- $\quad$ Auditing

- $\quad$ Due diligence on partners in the supply chain

- Company anti-corruption policies

- $\quad$ Anti-corruption standards in the company's corporate social responsibility agenda

(13) Do you feel the following external measures are effective in addressing corruption in the private sector? [Respondents will be able to select for each option: strongly agree, agree, disagree, strongly disagree, don't know]

- International conventions on bribery and corruption

- $\quad$ National anti-bribery laws

- $\quad$ Investigative journalism

- $\quad$ Multi-stakeholder initiatives involving business, government and civil society

(14) Any other suggestions/thoughts on business-to-business corruption / anticorruption in Romania? [open-ended question]

Appendix B. Cramer's V Correlations with Work Experience

Work Experience versus Bribe

\begin{tabular}{lccc}
\hline \multicolumn{4}{c}{ Symmetric Measures } \\
\hline \\
\multirow{2}{*}{ Nominal by Nominal } & Phi & Value & Approx. Sig. \\
& Cramer's V & 0.566 & 0.091 \\
& N of Valid Cases & 0.566 & 0.091 \\
\hline
\end{tabular}

Work Experience versus Fraud

\begin{tabular}{lccc}
\hline \multicolumn{4}{c}{ Symmetric Measures } \\
\hline \\
\multirow{2}{*}{ Nominal by Nominal } & Phi & Value & Approx. Sig. \\
& Cramer's V & 0.563 & 0.098 \\
& N of Valid Cases & 0.563 & 0.098 \\
\hline
\end{tabular}


Work Experience versus Gifts

\begin{tabular}{cccc}
\hline \multicolumn{4}{c}{ Symmetric Measures } \\
\hline \multirow{2}{*}{ Nominal by Nominal } & Phi & Value & Approx. Sig. \\
& Cramer's V & 0.666 & 0.003 \\
& N of Valid Cases & 0.666 & 0.003 \\
\hline
\end{tabular}

Work Experience versus Favours

\begin{tabular}{cccc}
\hline \multicolumn{4}{c}{ Symmetric Measures } \\
\hline \\
\multirow{2}{*}{ Nominal by Nominal } & Phi & 0.563 & Approx. Sig. \\
& Cramer's V & 0.563 & 0.096 \\
& N of Valid Cases & 120 & 0.096 \\
\hline
\end{tabular}

Work Experience versus Corruption evaluation

\begin{tabular}{cccc}
\hline \multicolumn{4}{c}{ Symmetric Measures } \\
\hline \multirow{2}{*}{ Nominal by Nominal } & Phi & Value & Approx. Sig. \\
& Cramer's V & 1.165 & 0.090 \\
& N of Valid Cases & 0.521 & 0.090 \\
\hline
\end{tabular}

Work Experience versus Barriers in corruption reduction

\begin{tabular}{cccc}
\hline \multicolumn{4}{c}{ Symmetric Measures } \\
\hline \multirow{2}{*}{ Nominal by Nominal } & Phi & 1.481 & Approx. Sig. \\
& Cramer's V & 0.604 & 0.000 \\
& & 120 & 0.000 \\
\hline \multirow{2}{*}{ N of Valid Cases } & & \\
\hline
\end{tabular}

\section{References}

1. Klitgaard, R.; Addressing Corruption Together. OECD Symposium on Anti-Corruption Development Assistance: Good Practices among Providers of Development Co-Operation. 2014, p. 18. Available online: https://www.oecd.org/dac/conflict-fragility-resilience/publications/FINAL\% 20Addressing\%20corruption\%20together.pdf (accessed on 15 April 2019).

2. The European Union. Fighting Corruption and Promoting Competition. 2014. Available online: http: //ec.europa.eu/competition/international/multilateral/2014_feb_fighting_corruption_en.pdf (accessed on 10 April 2019).

3. Sampford, C.; Shacklock, A.; Connors, C.; Galtung, F. Measuring Corruption; Ashgate Publishing: London, UK, 2006.

4. Pinto, J.; Leana, C.R.; Pil, F.K. Corrupt organizations or organizations of corrupt individuals? Two types of organization-level corruption. Acad. Manag. Rev. 2008, 33, 685-709. [CrossRef]

5. Bowen, H. Social Responsibilities of the Businessman; Harper and Row: New York, NY, USA, 1953; p. 6.

6. Di Nicola, A.; Espa, G.; Costantino, F.; Dickson, M.M. The Private Corruption Barometer. eCrime Research Reports 04. 2008, p. 5. Available online: https://www.researchgate.net/publication/330442286_The_Private_ Corruption_Barometer_Drafting_and_piloting_a_model_for_a_comparative_business_victimization_ survey_on_private_corruption_in_the_EU (accessed on 10 May 2019). 
7. Argandoña, A. Private to Private Corruption. J. Bus. Ethics 2003, 47. [CrossRef]

8. Sööt, M.-L.; Johannsen, L.; Pedersen, H.K.; Vadi, M.; Reino, A. Private-to-Private Corruption: Taking Business Managers' Risk Assessment Seriously When Choosing Anti-Corruption Measures. 2016 OECD Integrity Forum. Available online: https://www.oecd.org/cleangovbiz/Integrity-Forum-16-Soot-Johannsen-PedersenVadi-Reino.pdf (accessed on 12 March 2019).

9. Business Anti-Corruption Portal. Romania Corruption Report. Updated April 2017. Available online: https://www.business-anti-corruption.com/country-profiles/romania/ (accessed on 10 March 2019).

10. The European Commission. Progress Report Romania 2018. Cooperation and Verification Mechanism. COM (2018)851. 2018. Available online: https://ec.europa.eu/info/files/progress-report-romania-2018-com-2018851_en (accessed on 8 June 2019).

11. Transparency International. Corruption Perception Index 2018. Available online: https://www.transparency. org/files/content/pages/2018_CPI_FullResults.zip (accessed on 3 March 2019).

12. EY \& Hipo. Barometrul Încrederii Angajaților Români în Companii 2017. [The Barometer of Romanian Employees' Trust in Companies 2017]. 2017. Available online: http://media.hotnews.ro/media_server1/ document-2017-07-12-21889515-0-angajatii-romani-increderea-locul-munca-studiu-2017-12iulie17.pdf (accessed on 3 March 2019).

13. Kotkin, S.; Sajo, A. Political Corruption in Transition: A Skeptic's Handbook; CEU Press: New York, NY, USA, 2002.

14. Alatas, S.H. The Sociology of Corruption: The Nature, Function, Causes and Prevention of Corruption; D. Moore Press: Singapore, 1968.

15. Heidenheimer, A. Political Corruption: Readings in Comparative Analysis; Holt, Rinehart and Winston: New York, NY, USA, 1970.

16. Leys, C. What Is the Problem About Corruption? J. Mod. Afr. Stud. 1965, 3, 215-230. [CrossRef]

17. Krueger, A.O. The Political Economy of the Rent-Seeking Society. Am. Econ. Rev. 1974, 64, 291-303. Available online: http://www.jstor.org/view/00028282/di950083/95p00956/0 (accessed on 12 January 2019).

18. Diamond, L. Assessing Global Democratization a Decade after the Communist Collapse, Address to the Workshop on Democratization, New Europe College and Romanian Academic Society. 2002, p. 7. Available online: http://www.stanford.edu/\%7Eldiamond/papers/romania_speech.pdf (accessed on 12 January 2019).

19. Theobald, R. Corruption, Development, and Underdevelopment; Duke University Press: Durham, UK, 1990; pp. 126-128.

20. Mauro, P. Why Worry about Corruption? Int. Monet. Fund 1997. Available online: http://www.imf.org/ external/pubs/ft/issues6/index.htm\#Why (accessed on 3 March 2019).

21. Sidley Austin LLP. Anticorruption Quarterly Q4 2018. Available online: https://www.lexology.com/library/ detail.aspx?g=43842126-b8db-4543-8fa0-be2604dab24b (accessed on 23 May 2019).

22. Nye, J. Corruption and Political Development: A Cost-Benefit Analysis. Am. Political Sci. Rev. 1967, 61, 417-427. [CrossRef]

23. Robin, D.P.; Reidenbach, R.E. Social Responsibility, Ethics, and Marketing Strategy: Closing the Gap between Concept and Application. J. Mark. 1987, 51, 44-58. [CrossRef]

24. Edu, T.; Negricea, I.C. CSR Market Positioning Constructs: From Planning to Action. Evidence from Romanian Internet Service Providers. In The Dynamics of Corporate Social Responsibility; Springer: Cham, Switzerland, 2017; pp. 117-137.

25. Saurage-Altenloh, S.; Randall, P.M. The Influence of CSR on B2B Relationships: Leveraging Ethical Behaviors to Create Value. In Ethical Standards and Practice in International Relations; IGI Global: Hershey, PA, USA, 2018; pp. 1-21.

26. Sroka, W.; Lőrinczy, M. The perception of ethics in business: Analysis of research results. Procedia Econ. Financ. 2015, 34, 156-163. [CrossRef]

27. Transparency International. What Is Corruption? 2018. Available online: https://www.transparency.org/ what-is-corruption (accessed on 3 March 2019).

28. OECD Glossaries. Corruption. A Glossary of International Standards in Criminal Law; OECD Publishing: Paris, France, 2008.

29. Anand, V.; Ashforth, B.E.; Joshi, M. Business as usual: The acceptance and perpetuation of corruption in organizations. Acad. Manag. Exec. 2004, 18, 40. Available online: http://actoolkit.unprme.org/wp-content/ resourcepdf/anand_et_al._ame_2004.pdf (accessed on 23 April 2019). [CrossRef] 
30. Vveinhardt, J. Nepotism variations: Public and private sectors. Int. Conf. Achiev. High School 2012, 20, 123-134.

31. Lindskog, H.; Brege, S.; Brehmer, P.-O. Corruption in Public Procurement and Private Sector Purchasing. J. Organ. Transf. Soc. Chang. 2010, 7, 167-188. [CrossRef]

32. The Inter-American Convention against Corruption. 1996. Available online: http://www.oas.org/en/sla/dil/ docs/inter_american_treaties_B-58_against_Corruption.pdf (accessed on 22 April 2019).

33. The OECD Convention on Combating Bribery of Foreign Public Officials in International Business Transactions. 1997. Available online: https://www.oecd.org/daf/anti-bribery/ConvCombatBribery_ENG.pdf (accessed on 23 April 2019).

34. Council of the European Union. Joint Action of 22 December 1998 Adopted by the Council on the Basis of Article K.3 of the Treaty on European Union, on Corruption in the Private Sector. 1998. Available online: https://eur-lex.europa.eu/legal-content/EN/TXT/PDF/?uri=CELEX:31998F0742\&from=EN (accessed on 22 April 2019).

35. Council of Europe. Criminal Law Convention on Corruption. 1999. Available online: https://www.coe.int/ en/web/conventions/full-list/-/conventions/rms/090000168007f3f5 (accessed on 3 March 2019).

36. Council of the European Union. Council Framework Decision 2003/568/Jha of 22 July 2003 on Combating Corruption in the Private Sector. 2003. Available online: https://eur-lex.europa.eu/legal-content/EN/TXT/ PDF/?uri=CELEX:32003F0568\&from=en (accessed on 12 January 2019).

37. United Nations. United Nations Convention against Corruption (UNCAC). 2003. Available online: https: //www.unodc.org/documents/brussels/UN_Convention_Against_Corruption.pdf (accessed on 10 January 2019).

38. Park, H. Determinants of corruption: A cross-national analysis. Multinatl. Bus. Rev. 2003, 11, 29-48. [CrossRef]

39. Ali, A.M.; Isse, H.S. Determinants of economic corruption: A cross-country comparison. Cato J. 2002, $22,449$.

40. Economakis, G.; Rizopoulos, Y.; Sergakis, D. Patterns of corruption. East-West J. Econ. Bus. 2010, 11-31.

41. Kaufmann, D.; Kraay, A.; Mastruzzi, M. Measuring Corruption: Myths and Realities. World Bank Institute [Internet]. 2006, p. 1. Available online: http://www1.worldbank.org/devoutreach/article.asp?id=371 (accessed on 22 April 2019).

42. Gopinath, C. Recognizing and Justifying Private Corruption. J. Bus. Ethics 2008, 82, 747-754. [CrossRef]

43. Goel, R.K.; Budak, J.; Rajh, E. Private sector bribery and effectiveness of anti-corruption policies. Appl. Econ. Lett. 2015, 22, 759-766. [CrossRef]

44. Del Monte, A.; Papagni, E. The determinants of corruption in Italy: Regional panel data analysis. Eur. J. Political Econ. 2007, 23, 379-396. [CrossRef]

45. Sanyal, R. Determinants of bribery in international business: The cultural and economic factors. J. Bus. Ethics 2005, 59, 139-145. [CrossRef]

46. Kapoor, M.; Ravi, S. Determinants of corruption: Government effectiveness vs. cultural norms. BE J. Econ. Anal. Policy 2012, 12. [CrossRef]

47. Transparency International. The Corruption Perception Index (CPI). Overview. 2018. Available online: https://www.transparency.org/research/cpi/overview (accessed on 4 February 2019).

48. Transparency International. The Global Corruption Barometer (GCB). Overview. 2018. Available online: https://www.transparency.org/research/gcb/overview (accessed on 4 February 2019).

49. Transparency International. Putting Corruption Out of Business: Lost Business Due to Bribery. 2011. Available online: https://www.transparency.org/news/feature/putting_corruption_out_of_business (accessed on 4 February 2019).

50. The European Commission. Business Attitudes towards Corruption in the EU. Flash Eurobarometer 374. February 2014. Available online: http://ec.europa.eu/commfrontoffice/publicopinion/flash/fl_374_en.pdf (accessed on 10 January 2019).

51. The World Bank. Enterprise Surveys. What Businesses Experience. Available online: https://www. enterprisesurveys.org/data/exploretopics/corruption (accessed on 8 February 2019).

52. Control Risks. International Business Study Attitudes to Corruption Survey 2015-2016. 2016. Available online: http://rai-see.org/wp-content/uploads/2016/01/corruption-survey-2016.pdf (accessed on 12 January 2019). 
53. Transparency International. Bribe Payers' Index. 2011. Available online: http://files.transparency.org/content/ download/98/395/file/2011_BPI_EN.pdf (accessed on 12 January 2019).

54. United Nations Office on Drugs and Crime. Corruption in Croatia: Bribery as Experiences by the Population. Available online: https://www.unodc.org/documents/data-and-analysis/statistics/corruption/ Croatia_corruption_report_web_version.pdf (accessed on 4 February 2019).

55. Johannsen, L.; Pedersen, K.H.; Vadi, M.; Reino, A.; Sööt, M.-L. Private-to-Private Corruption: A Survey on Danish and Estonian Business Environment; Justiitsministeerium (Ministry of Justice): Aarhus, Denmark, 2016.

56. Rose-Ackerman, S. Measuring Private Corruption. UP4Brief, September 2007; No. 5. Available online: https://www.u4.no/publications/measuring-private-sector-corruption.pdf (accessed on 23 May 2019).

57. Fan, Y. Ganxi's consequences: Personal gains at social cost. J. Bus. Ethics 2002, 38, 371-380. [CrossRef]

58. Kozminski, A.K. From the Communist Nomenklatura to Transformational Leadership: The Role of Management in the Post-communist Enterprises. In Social Change and Modernization: Lessons from Eastern Europe; Grancelli, B., Ed.; Walter de Gruyter: Berlin, Germany; New York, NY, USA, 1995; pp. 83-105.

59. Zaharia, R.M. Business Ethics in Transition: Communism to Commerce in Central Europe and Russia. In The Routledge Companion to Business Ethics; Heath, E., Kaldis, B., Marcoux, A., Eds.; Routledge: London, UK, 2018; pp. 657-673.

60. Transparency International. The Corruption Perception Index (CPI). Romania. 2018. Available online: https://www.transparency.org/country/ROU (accessed on 2 April 2019).

61. Transparency International. People and Corruption: Europe and Central Asia. Global Corruption Barometer. 2016. Available online: https://www.kpk-rs.si/kpk/wp-content/uploads/2018/03/2016_GCB_ECA_EN.pdf (accessed on 1 June 2019).

62. Bertelsmann Stiftung. Sustainable Governance Indicators. Quality of Democracy. Rule of Law. 2018. Available online: http://www.sgi-network.org/2018/Democracy/Quality_of_Democracy/Rule_of_Law (accessed on 12 March 2019).

63. Ștefan, L.; Ioniță, S.; Pârvu, S. Nations in Transit 2018 Report on Romania. 2018. Available online: https://freedomhouse.org/sites/default/files/NiT2018_Romania.pdf (accessed on 12 March 2019).

64. Kaufmann, D.; Kraay, A. Worldwide Governance Indicators (WGI). 2018. Available online: https://info. worldbank.org/governance/wgi/\#reports (accessed on 3 March 2019).

65. European Commission. Flash Eurobarometer 457: Business Attitudes toward Corruption. 2017. Available online: http://ec.europa.eu/commfrontoffice/publicopinion/index.cfm/ResultDoc/download/DocumentKy/ 81005 (accessed on 12 January 2019).

66. European Commission. Special Eurobarometer 470: Corruption. 2017. Available online: http://ec.europa.eu/ commfrontoffice/publicopinion/index.cfm/ResultDoc/download/DocumentKy/81007 (accessed on 12 January 2019).

67. Hosmer, L.T. Trust: The connecting link between organizational theory and philosophical ethics. Acad. Manag. Rev. 1995, 20, 379-403. [CrossRef]

68. Petersen, R.D.; Valdez, A. Using snowball-based methods in hidden populations to generate a randomized community. Youth Violence Juvenile Justice 2005, 3, 151-167. [CrossRef]

69. Romanian Companies Database. Available online: https://www.romanian-companies.eu/ (accessed on 10 January 2019).

70. Transparency International. Corruption Perceptions Index 2018: Full Source Description. 2018. Available online: https://www.transparency.org/files/content/pages/2018_CPI_Methodology.zip (accessed on 10 March 2019).

71. Cohen, J. A Power Primer. Psychol. Bull. 1992, 112, 155-159. [CrossRef] [PubMed]

72. Pellegrini, L. Causes of corruption: A survey of cross-country analyses and extended results. In Corruption, Development and the Environment; Springer: Dordrecht, The Netherlands, 2011; pp. 29-51.

73. Treisman, D. The causes of corruption: A cross-national study. J. Public Econ. 2000, 76, 399-457. [CrossRef]

74. La Porta, R.; Lopez-de-Silanes, F.; Shleifer, A.; Vishny, R.W. The quality of government. J. Econ. Law Organ. 1999, 15, 222-279. [CrossRef] 
75. Olsen, W.P.; Petkoski, D.; Greenhalgh, S. Case for Collective Action; The World Bank Institute: Washington, DC, USA, December 2009.

76. International Organization for Standardization. ISO 37001: Anti-Bribery Management Systems. 2016. Available online: https://www.iso.org/files/live/sites/isoorg/files/archive/pdf/en/iso_37001_anti_bribery_mss. pdf (accessed on 12 January 2019). 